\title{
Critically ill COVID-19 patients: a sociodemographic and clinical profile and associations between variables and workload
}

\author{
Pacientes críticos com COVID-19: perfil sociodemográfico, clínico e associações entre variáveis e carga de trabalho
}

Pacientes críticos con Covid-19: perfil sociodemográfico, clínico y asociaciones entre variables y carga de trabajo

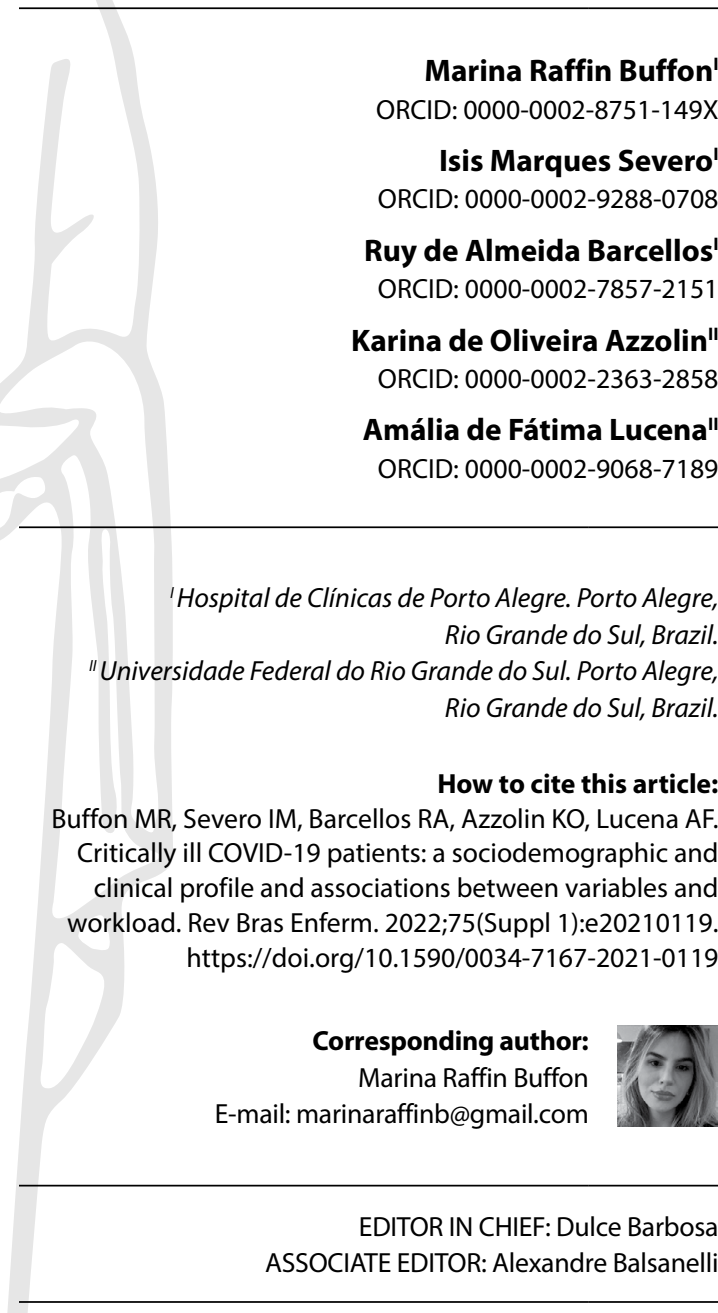

Submission: 03-07-2021

Approval: 09-01-2021

\begin{abstract}
Objective: To identify the sociodemographic and clinical profile of COVID-19 patients; measure workload and make associations between clinical variables. Methods: Crosssectional study with 150 adult COVID-19 patients in an intensive care unit (from March to June 2020). Data from the electronic medical record in the first 24 hours of hospitalization: gender, age, education, origin, comorbidities, invasive mechanical ventilation, prone maneuver, renal replacement therapy, pressure injury, Braden, Nursing Activities Score, diagnoses, and nursing care. Descriptive statistical analysis, associations between clinical variables and age group. Results: Male (55.3\%); mean age, 59 years; hypertensive (57.3\%); obese (50.6\%); diabetic (34\%); invasive mechanical ventilation (66.7\%); pronated (20.6\%); hemodialysis (15.3\%); Nursing Activities Score average, 86\%. Twenty-eight nursing diagnoses and 73 cares were found. Conclusion: Patients required highly complex support. There was a significant association between pressure injury and workload with the prone maneuver. Nursing diagnoses and care reflect the needs of critical patients.
\end{abstract}

Descriptors: Coronavirus Infections; Intensive Care Units; Nursing Process; Workload; Nursing Diagnosis

\section{RESUMO}

Objetivo: Identificar o perfil sociodemográfico e clínico de pacientes com COVID-19; mensurar carga de trabalho e realizar associações entre variáveis clínicas. Métodos: Estudo transversal, 150 pacientes adultos com COVID-19 em unidade de terapia intensiva (marçojunho/2020). Dados do prontuário eletrônico nas primeiras 24 horas de internação: sexo, idade, escolaridade, procedência, comorbidades, ventilação mecânica invasiva, manobra prona, terapia renal substitutiva, lesão por pressão, Braden, Nurging Activies Score, diagnósticos e cuidados de enfermagem. Análise estatística descritiva, associações entre variáveis clínicas e grupo etário. Resultados: Sexo masculino (55,3\%); idade média, 59 anos; hipertensos $(57,3 \%)$; obesos $(50,6 \%$ ); diabéticos (34\%); ventilação mecânica invasiva (66,7\%); pronados (20,6\%); hemodiálise (15,3\%); média do Nursing Activities Score, 86\%. Encontraram-se 28 diagnósticos de enfermagem e 73 cuidados. Conclusão: Pacientes necessitaram de suporte de alta complexidade. Houve associação significante entre lesão por pressão e carga de trabalho com manobra prona. Os diagnósticos e cuidados de enfermagem refletem necessidades dos pacientes críticos.

Descritores: Infecções por Coronavírus; Unidades de Terapia Intensiva; Processo de Enfermagem; Carga de Trabalho; Diagnóstico de Enfermagem

\section{RESUMEN}

Objetivo: Identificar perfil sociodemográfico y clínico de pacientes con COVID-19; mensurar carga de trabajo y realizar asociaciones entre variables clínicas. Métodos: Estudio transversal, 150 pacientes adultos con COVID-19 en unidad de cuidados intensivos (marzo-junio/2020). Datos del prontuario electrónico en las primeras 24 horas de internación: sexo, edad, escolaridad, procedencia, comorbilidad, ventilación mecánica invasiva, maniobra lista, terapia renal substitutiva, lesión por presión, Braden, Nurging Activies Score, diagnósticos y cuidados de enfermería. Análisis estadístico descriptivo relaciones entre variables clínicas y grupo de edad. Resultados: Sexo masculino (55,3\%); edad mediana, 59 años; hipertensos (57,3\%); obesos (50,6\%); diabéticos (34\%); ventilación mecánica invasiva (66,7\%); inclinados (20,6\%); hemodiálisis (15,3\%); mediana del Nursing Activities Score, 86\%. Encontrados 28 diagnósticos de enfermería y 73 cuidados. Conclusión: Pacientes necesitaran de soporte de alta complejidad. Hubo relación significante entre lesión por presión y carga de trabajo con maniobra lista. Diagnósticos y cuidados de enfermería reflejan necesidades de los pacientes críticos.

Descriptores: Infecciones por Coronavirus; Unidades de Cuidados Intensivos; Proceso de Enfermería; Carga de Trabajo; Diagnóstico de Enfermería. 


\section{INTRODUCTION}

In late December 2019, Chinese authorities, specifically from the city of Wuhan, identified patients with pneumonia of an unknown etiology, which had spread to thousands of cases in less than two months ${ }^{(1)}$. From this, researchers discovered the cause of these illnesses, which were related to the new coronavirus SARS-CoV-2, whose disease was named by the World Health Organization (WHO) as Coronavirus Disease 2019 (COVID-19) ${ }^{(2)}$.

Patients diagnosed with COVID-19 may progress to more severe disease conditions such as acute respiratory distress syndrome (ARDS), shock, and multiple organ failure, requiring admission to the Intensive Care Unit (ICU) ${ }^{(3)}$. International studies have verified that most patients admitted to the ICU require invasive mechanical ventilation (IMV) and $85 \%$ of these develop mild to moderate ARDS ${ }^{(4-5)}$.

The COVID-19 severity among patients influences the increased complexity of nursing care due to procedures and technologies used for supportive therapies, such as invasive mechanical ventilation, renal replacement therapy, extracorporeal membrane oxygenation (ECMO) and, often, prone maneuver in patients with severe lung injury ${ }^{(6)}$. In addition to direct patient care, nursing must deal with the imminent risk of disease contamination, requiring additional care for preventing the spread of the virus, in addition to the use of personal protective equipment, which also contributes to increased workload of the nursing team ${ }^{(7)}$.

In Italy, nursing team's workload was measured using the Nursing Activities Score (NAS) instrument, and a significant increase in the score of $33 \%$ was identified ${ }^{(6)}$. A study carried out in Belgium compared the average NAS in the ICU for both COVID-19 and non-COVID patients, showing that the average NAS significantly increased by $20 \%$ for the COVID-19 group $^{(8)}$. In Brazil, the lack of studies that address this issue in intensive care stands out as a gap. In addition, in this complex care scenario, nursing professionals working on the front line of COVID-19 care need information to better understand the profile of these patients who require continuous monitoring care, early identification of changes in organic systems and, especially, management of complex therapeutic support technologies and immediate emergency interventions.

It is also essential to deepen the knowledge of elements of nursing practice, such as nursing diagnoses (NDs), which support the planning of care to be implemented for the patient ${ }^{(9)}$, since this disease was unknown and, until now, few studies address this issue - none of them in a real care setting ${ }^{(10-11)}$.

Thus, studying the sociodemographic and clinical profile of patients with COVID-19, including diagnoses and nursing care, is a current need. The best scientific evidence on this clinical condition must be sought to provide assistance and, thus, obtain the best possible results in the care of these patients. Knowing the profile of critically ill patients with COVID-19 and the complexity of their care will possibly contribute to nursing planning actions, both for care and workload management, as new waves of COVID-19 can still occur in Brazil.

\section{OBJECTIVE}

To identify the sociodemographic and clinical profile of patients with COVID-19; measure the workload and make associations between clinical variables in the first 24 hours of hospitalization.

\section{METHODS}

\section{Ethical aspects}

This research is part of a larger project entitled "Clinical and epidemiological profile of patients admitted to the intensive care unit: analysis of care, safety, outcomes, and educational strategies", approved by the institution's Research Ethics Committee. The study was exempt from requiring an Informed Consent Form (FICF) considering that it only used data obtained from the patients' electronic medical records.

\section{Study type}

Cross-sectional study, developed from March to June 2020 and guided by the STROBE tool.

\section{Study location}

The study was held at the adult ICU of a large public and university hospital in the city of Porto Alegre, state of Rio Grande do Sul (RS), Brazil, a reference in COVID-19 patient care. The ICU area is highly complex and was expanded during the study period, reaching 105 new beds for the care of suspected or confirmed cases of the disease. There was a need for emergency hiring of about 524 nursing professionals due to the growing demand for beds. In this ICU, the nurse is responsible for the care of an average of five patients; and the nursing technician, two patients at each shift.

All stages of the nursing process (NP), which include the NDs and prescribed nursing care, are registered in an electronic medical record. The NDs are described based on the NANDAInternational (NANDA-I) ${ }^{(9)}$ taxonomy and associated with Teoria das Necessidades Humanas Básicas de Wanda Horta [Wanda Horta's Theory of Basic Human Needs] ${ }^{(12)}$. Nursing care is based on the Nursing Interventions Classification (NIC) ${ }^{(13)}$.

\section{Population and sample}

The study population consisted of COVID-19 adult patients admitted to intensive care. The non-probabilistic sample included all patients, from the first registered case admitted to the ICU in question, aged 18 years or over with a positive RT-PCR test for SARS-CoV-2 in the ICU from March to June 2020, totaling 150 patients. This period was defined as being the beginning of the pandemic in Brazil, with a rapid increase in the number of cases, especially hospitalizations of critically ill patients, which required important adjustments in the nursing work process. Exclusion criteria were not foreseen.

\section{Study variables}

The sociodemographic variables were gender, age, education and origin. The clinical variables were comorbidities, use of IMV, prone maneuver, hemodialysis, presence of pressure injury (PI), ECMO, NAS, Braden Scale score, NDs, and nursing care.

\section{Data collection}

Sociodemographic and clinical data were collected retrospectively from patients' electronic medical records, considering the 
first 24 hours in the ICU, that is, from the period of admission to the following day. An active search for cases was carried out daily by the researcher responsible for the collection logistics. The collected data were organized in the Excel program (Microsoft Office 2013), version 15.0, according to the investigated variables.

\section{Data analysis}

Data were analyzed using Excel and SPSS (version 22) software. Initially, descriptive analysis was performed. Continuous variables, in the case of normal distribution, were expressed as mean and standard deviation; and, if asymmetric, as median and interquartile range. Data normality was tested using the Kolmogorov-Smirnov test and histograms.

The association of variables was verified using Student's t test for independent samples, according to their distribution; and for categorical data, Pearson's chi-squared test was used, considering a significance level of $5 \%(p<0.05)$.

The workload measured by the NAS ${ }^{(14)}$ was classified into categories, defined based on a previous study ${ }^{(15)}$ : NAS $\leq 50 \%=$ mild; NAS from $50.1 \%$ to $100 \%=$ moderate/high; and NAS $\geq 100 \%=$ very high .

\section{RESULTS}

One hundred and fifty medical records of patients with a positive SARS-CoV-2 test, admitted to the ICU between March and June 2020, were evaluated. Among their sociodemographic characteristics, a higher prevalence of males (55\%) and mean age of 59 years (SD \pm 14.2 ) were identified. The other sample characteristics are described in Table 1.

Table 1 - Sociodemographic characteristics of COVID-19 patients $(N=150)$, Porto Alegre, Rio Grande do Sul, Brazil, 2020

\begin{tabular}{lcc}
\hline Characteristics & $\mathbf{n}$ & (\%) \\
\hline Age (years) & & \\
$18-40$ & 16 & $(10.6)$ \\
$41-60$ & 64 & $(42.6)$ \\
$>60$ & 70 & $(46.6)$ \\
Education & & \\
$\quad$ Elementary school & 95 & $(63.3)$ \\
$\quad$ High school & 47 & $(31.3)$ \\
$\quad$ College degree & 8 & $(5.5)$ \\
Origin & & \\
$\quad$ Porto Alegre & 70 & $(46.7)$ \\
$\quad$ Greater Porto Alegre & 44 & $(29.3)$ \\
$\quad$ Interior of the state & 36 & $(24)$ \\
\hline
\end{tabular}

Among the studied patients, 100 (66.7\%) of them required IMV, and 31 (20.6\%) underwent the prone maneuver within the first 24 hours. The mean BMl found was $31.6 \mathrm{~kg} / \mathrm{m}^{2}$ (SD \pm 6.8 ). There was no significant association between obesity $\left(B M I \geq 30 \mathrm{~kg} / \mathrm{m}^{2}\right)$ and IMV $(p=0.83)$, nor between obesity and the prone maneuver $(p=0.08)$.

In pronated patients, pressure injuries (PIs) were identified in 12 (38.7\%). The Pls presented as blisters and ruptured blisters, with the chest, face and iliac crest as the main sites affected. There was a significant association between the development of PI and the prone position ( $p \leq 0.001$ ). There was no association between obesity and the development of PI $(p=1.0)$. The mean of the Braden Scale score in the sample was 12 (SD \pm 3.8 ); in patients in the prone position and who developed $\mathrm{Pl}$, the mean was 10 (SD \pm 10$)$. Table 2 shows the associations between age group and clinical variables.

Table 2 - Association between age group and clinical variables in the first 24 hours of admission of patients with COVID-19 in the Intensive Care Unit $(N=150)$, Porto Alegre, Rio Grande do Sul, Brazil, 2020

\begin{tabular}{|c|c|c|c|c|}
\hline Comorbidities & $\begin{array}{c}18-60 \\
\text { years } \\
\mathrm{n}=80 \\
(\%)\end{array}$ & $\begin{array}{c}>60 \text { years } \\
n=70 \\
(\%)\end{array}$ & $\begin{array}{c}\text { Total } \\
\mathbf{n}=150 \\
(\%)\end{array}$ & $\underset{\text { value* }}{p}$ \\
\hline Systemic arterial hypertension & $38(47.5)$ & $48(68.6)$ & $86(57.3)$ & 0.013 \\
\hline Obesity - BMI $\geq 30 \mathrm{~kg} / \mathrm{m}^{2}$ & $54(67.5)$ & $22(31.4)$ & $76(50.6)$ & $<0.001$ \\
\hline Diabetes melittus 2 & $19(23.8)$ & $32(45.7)$ & $51(34)$ & 0.006 \\
\hline Respiratory disorders & $15(18.8)$ & $21(30)$ & $36(24)$ & 0.127 \\
\hline Smoking (in abstinence) & $8(10)$ & $23(32.9)$ & $31(20.7)$ & $<0.001$ \\
\hline Heart Diseases & $7(8.8)$ & $21(30)$ & $28(18.7)$ & $<0.001$ \\
\hline Stroke & $4(5)$ & $11(15.7)$ & $15(10)$ & 0.053 \\
\hline Kidney disease & $6(7.5)$ & $6(8.6)$ & $12(8)$ & 1.0 \\
\hline Immune disease & $7(8.8)$ & $1(1.4)$ & $8(5.3)$ & 0.068 \\
\hline Cancer & $1(1.3)$ & $3(4.3)$ & $4(2.7)$ & 0.261 \\
\hline Active smoker & $2(2.5)$ & $2(2.9)$ & $4(2.7)$ & 1.0 \\
\hline No comorbidities & $18(22.5)$ & $4(5.7)$ & $22(14.6)$ & 0.003 \\
\hline \multicolumn{5}{|l|}{ Clinical data } \\
\hline Invasive Mechanical Ventilation & $48(60)$ & $52(74.3)$ & $100(66.7)$ & 0.046 \\
\hline Prone maneuver & 15 (18.8) & $16(22.9)$ & $31(20.6)$ & 0.338 \\
\hline Hemodialysis & $11(13.8)$ & $12(17.1)$ & $23(15.3)$ & 0.363 \\
\hline Pressure injury & $3(3.8)$ & $9(12.9)$ & $12(8)$ & 0.039 \\
\hline $\mathrm{ECMO}^{* *}$ & $1(1.25)$ & - & $1(0.6)$ & \\
\hline
\end{tabular}

*chi-squared test; (-) numeric data equal to zero, not resulting from rounding. ${ }^{* *} \mathrm{ECMO}$ - extracorporeal membrane oxygenation.

Twenty-eight different NDs were listed for the studied patients. The average of NDs found per patient was 5 (SD \pm 3.4$)$. The most prevalent NDs are described in Table 3.

Table 3 - Nursing diagnoses identified in patients with COVID-19 admitted to the Intensive Care Unit ( $=150)$, Porto Alegre, Rio Grande do Sul, Brazil, 2020

\begin{tabular}{lcc}
\hline Nursing Diagnosis & $\mathbf{n}$ & $\mathbf{( \% )}$ \\
\hline Risk of infection & 148 & $(98.7)$ \\
Self-care deficit syndrome & 103 & $(68.7)$ \\
Impaired spontaneous ventilation & 83 & $(55.3)$ \\
Risk for adult pressure injury & 75 & $(50)$ \\
Risk for corneal injury & 56 & $(37.3)$ \\
Ineffective breathing pattern & 54 & $(36)$ \\
Self-care deficit: bathing and/or hygiene & 32 & $(21.3)$ \\
Impaired gas exchange & 13 & $(8.7)$ \\
Ineffective renal tissue perfusion* & 11 & $(7.3)$ \\
Impaired tissue integrity & 10 & $(6.6)$ \\
Acute pain & 8 & $(5.3)$ \\
Risk for impaired skin integrity & 5 & $(3.3)$ \\
Risk for bleeding & 4 & $(2.7)$ \\
Impaired physical mobility & 4 & $(2.7)$ \\
Discomfort & 4 & $(2.7)$
\end{tabular}

Each patient can have more than one listed ND. *This ND is no longer part of NANDA-I Taxonomy II since the 2009-2011 version, but it is still used in the computerized system of the studied institution.

The less frequent NDs $(n=2)$ listed by nurses were: Impaired skin integrity, Impaired urinary elimination, Ineffective tissue perfusion: cardiopulmonary, Risk of allergic response, Decreased cardiac output, Risk of ineffective cerebral tissue perfusion, Risk of unstable blood glucose, Risk of shock, Diarrhea, Excessive fluid volume, Risk of adverse drug reactions, Risk of electrolyte imbalance and Risk of vascular dysfunction, corresponding to $1.3 \%$ each. 
For each ND listed, a total of 73 different nursing care procedures were prescribed. The average of prescribed care per patient was 30 (SD \pm 4.5 ). Nursing care items are described in Table 4.

The workload of the nursing team was measured using the NAS instrument in the first 24 hours of admission to the ICU. The NAS mean identified was of $86 \%$ (SD \pm 20.3 ), which is equivalent to 20.6 hours of nursing care in a 24-hour period. The scores identified were: 7 (4.7\%) patients demanded a light workload from nursing; 110 (73.3\%), moderate/high; 33 (22\%), very high. The mean NAS of the pronated patients was $97.5 \%(S D \pm 18.1)$, and the mean in hemodialysis patients was $96 \%(S D \pm 8.1$ ), that is, equivalent to a moderate/high workload. A significant association was found between the workload of the nursing team and the performance of the prone maneuver $(p \leq 0.001)$.

Table 4 - Prescribed nursing care for COVID-19 patients according to the nursing diagnoses listed and categorized as per Wanda Horta's psychobiological needs subgroups, Porto Alegre, Rio Grande do Sul, Brazil, 2020

\begin{tabular}{|c|c|c|}
\hline Subgroups/ Diagnoses/Nursing care & $\mathbf{n}$ & (\%) \\
\hline \multicolumn{3}{|l|}{ Physical security/Environment: } \\
\hline \multicolumn{3}{|l|}{ Risk of infection, Risk of adverse drug reactions } \\
\hline Dressing the central venous catheter & 103 & (68.7) \\
\hline Replacing valves - oxygen extender & 100 & $(66.7)$ \\
\hline Implement care in accordance with the patient fall care protocol & 96 & $(64.0)$ \\
\hline Apply arterial catheter dressing & 95 & (63.7) \\
\hline Change aspirator bottle and extender & 94 & (62.7) \\
\hline Disinfect connections with a $70 \%$ alcohol sachet after each handling & 94 & (62.7) \\
\hline Implement precautionary measures for aerosols & 93 & (62.0) \\
\hline Implement precautionary measures for droplets & 91 & $(60.7)$ \\
\hline Change blood pressure transducer & 91 & (60.7) \\
\hline Change equipment, extenders and cannulas as per routine & 89 & $(59.3)$ \\
\hline Change closed suction system & 88 & $(58.3)$ \\
\hline Change the ventilatory system's bacterial filter & 87 & $(58.0)$ \\
\hline Apply standard disinfectant to equipment and surfaces & 85 & (56.7) \\
\hline Apply $2 \%$ aqueous chlorhexidine to the body, followed by changing the set of cardiac electrodes & 81 & (54.0) \\
\hline Dressing the peripheral venous catheter & 80 & $(53.3)$ \\
\hline Implement care in the collection of laboratory tests & 70 & $(46.7)$ \\
\hline Change diet infusion pump set & 70 & $(46.7)$ \\
\hline Implement contact precaution measures & 44 & (29.3) \\
\hline Restrict visits & 39 & $(26.0)$ \\
\hline Implement care with the mechanical containment of the adult patient & 34 & $(22.7)$ \\
\hline Dressing the central catheter for hemodialysis & 26 & $(17.2)$ \\
\hline \multicolumn{3}{|l|}{ Oxygenation: } \\
\hline Keep headboard elevated & 111 & $(74.4)$ \\
\hline Measure cuff pressure & 93 & $(62.0)$ \\
\hline Check oximetry & 91 & $(60.7)$ \\
\hline Implement oxygen therapy care - mechanical ventilation & 81 & (54.0) \\
\hline Implement care with tracheal and oropharyngeal aspiration & 77 & $(51.3)$ \\
\hline Aspirate secretions & 72 & $(48.0)$ \\
\hline Communicate ventilatory pattern changes & 67 & (44.7) \\
\hline Implement oxygen therapy care - nasal catheter & 63 & (42.0) \\
\hline Upkeep face mask with reservoir & 60 & $(40.0)$ \\
\hline Upkeep eye protection & 60 & $(40.0)$ \\
\hline Implement care with nasopharynx and oropharynx aspiration & 55 & (36.7) \\
\hline Alternate eye occlusion & 28 & (18.7) \\
\hline Implement oxygen therapy care - non-invasive mechanical ventilation & 21 & $(14.0)$ \\
\hline \multicolumn{3}{|l|}{ Body care: } \\
\hline \multicolumn{3}{|l|}{ Self-care deficit syndrome, Self-care deficit: bathing and/or hygiene } \\
\hline Perform bed bath & 120 & $(80.0)$ \\
\hline Perform oral hygiene by applying standard mouthwash & 119 & (79.3) \\
\hline Perform oral hygiene applying $0.12 \%$ aqueous chlorhexidine & 112 & (74.7) \\
\hline Perform urinary meatus hygiene & 107 & (71.3) \\
\hline Check external measurement of gastric/enteral tube & 101 & $(67.3)$ \\
\hline Change disposable diapers & 83 & $(55.3)$ \\
\hline Maintain nasoenteric tube care & 83 & (55.3) \\
\hline Apply medium-chain triglyceride & 81 & $(54.0)$ \\
\hline Perform facial trichotomy & 81 & $(54.0)$ \\
\hline Change probe fixture & 79 & $(52.7)$ \\
\hline Perform eye hygiene & 75 & $(50.0)$ \\
\hline Sanitize scalp; perform perineal hygiene & 72 & $(48.0)$ \\
\hline Wash enteric/gastric tube with $20 \mathrm{ml}$ of water & 59 & (39.3) \\
\hline Warm the patient with a thermal blanket or blankets & 30 & $(20.0)$ \\
\hline
\end{tabular}


Vascular:

Risk of bleeding, Ineffective tissue perfusion: cardiopulmonary, Decreased cardiac output, Risk of shock, Risk of vascular dysfunction

Check vital signs

Administer saline flush in the arterial vascular access

Evaluate extremity perfusion

Salinate peripheral venous catheter

Implement venipuncture care

Communicate change in level of consciousness

Warm lower limbs with laminated cotton

Monitor for signs of bleeding

Implement full anticoagulation care

$\begin{array}{cc}114 & (76.0) \\ 85 & (56.7) \\ 56 & (37.3) \\ 54 & (36.0) \\ 52 & (34.7) \\ 47 & (31.3) \\ 28 & (18.7) \\ 25 & (16.7) \\ 13 & (8.7)\end{array}$

Skin and mucosal integrity:

Risk of pressure injury, Impaired skin integrity, Impaired tissue integrity, Risk of impaired skin integrity, Impaired physical mobility

Implement care protocol for the prevention and treatment of $\mathrm{PI}$

Perform position change

Protect the skin on bony prominences

Upkeep airflow mattress

Moisturize the skin

Use a malleolus heel protective boot

Elevate limb(s) - change swimmer position - when prone

Hydration:

Change in tissue perfusion: renal, Excessive fluid volume, Risk of electrolyte imbalance

Check the patient's weight

Perform a complete water balance

Perform a partial water balance

Implement care in preparing for hemodialysis installation

Implement care in the installation of hemodialysis in the double-lumen catheter

Implement care at the end of the hemodialysis session

Excretion:

Impaired urinary excretion, Diarrhea

Measure diuresis

Implement care with indwelling urinary catheter

Record aspects and frequency of excretions

Note: Nursing diagnoses are classified in BHNs, in the institution's electronic system, and some care is included in more than one ND.

\section{DISCUSSION}

In this research, there was a prevalence of males, and the mean age was 59 years. Studies carried out in different countries (such as the United States, Italy, and Spain) with coronavirus infected patients identified a profile like this study, but the mean age was above 63 years ${ }^{(16-18)}$. In Brazil, before the pandemic, in an ICU in Porto Alegre, the mean age was 64 years ${ }^{(19)}$, however, in this sample of patients with COVID-19, there was a significant number of younger adults, which may be related to greater exposure to the disease.

Most patients have a low level of education, which is in line with the fact that this population is economically less favored and commonly hospitalized in public hospitals. Still, it is inferred that their housing conditions did not favor social distancing ${ }^{(20)}$. The literature demonstrates that the level of education is associated with the severity of the disease and that populations historically affected by health disparities, including racial and ethnic minorities, were disproportionately affected and hospitalized with COVID-19(21).

Another relevant finding was that 129 (86\%) patients had some associated comorbidity, the most prevalent being systemic arterial hypertension (SAH), obesity, and type 2 diabetes mellitus (DM2). These results corroborate the reality observed in different countries regarding intensive care for patients with COVID-19 ${ }^{(22-23)}$. The prevalence of $\mathrm{SAH}$ and DM2 is significantly associated with the above 60 years age group and with increased mortality and morbidity in patients with COVID19 ${ }^{(24-25)}$. In China, researchers have shown that DM2 is related to a fourfold increased risk of the patient developing the severe form of the disease ${ }^{(26)}$.

Obesity was the most prevalent comorbidity in patients under 60 years of age. It is known that this disease is an independent risk factor for respiratory failure and hospital mortality ${ }^{(27)}$. This association is related to the underlying characteristics of individuals with obesity that influence the physiological response to infection ${ }^{(28)}$. Furthermore, obesity is associated with a higher risk of developing severe ARDS in the context of COVID-19(27). However, in this research, there was no significant association between the use of IMV nor the prone maneuver and obesity during the first 24 hours of hospitalization.

The literature demonstrates that acute respiratory failure is the main cause of hospitalization of patients with COVID-19 in critical care units, which may progress to ARDS ${ }^{(29)}$. Therefore, IMV is the main supportive treatment for these patients. In this research, 100 (66.6\%) patients required IMV within the first 24 hours of hospitalization, and $74.3 \%$ were aged over 60 years. In Italy, a higher percentage was found: $88 \%$ of patients required IMV within the first 24 hours of hospitalization in the COVID ICU ${ }^{(17)}$.

The prone maneuver was performed in patients with severe ARDS with a PaO2/FiO2 ratio lower than $150 \mathrm{mmHg}^{(29)}$. The 31 (20.6\%) prone patients remained in this position for approximately 16 hours. Despite intense care to prevent PIs, 12 (35.5\%) 
developed them after the maneuver. Hypoxemia, microvascular injury, and thrombosis can increase the risk of $\mathrm{PI}$, and these clinical conditions are present in many patients with severe COVID-19(30). Severe hypoxemia results in a decrease in peripheral perfusion, including skin perfusion, and promotes the occurrence of these ischemic skin lesions ${ }^{(30)}$. It is observed that the prone position and associated physiological conditions are important risk factors for the development of $\mathrm{PI}$, which is in aligned with the low Braden scale scores identified for these patients.

The COVID-19 pandemic brought several challenges to the nursing team. Among them, the increased severity and complexity of patient care, who need different technologies for therapeutic support. In this sense, the average NAS found in this study was $86 \%$, equivalent to 20.6 hours of nursing care in a 24 -hour period. In comparison with the NAS of the non-COVID ICU, in the same hospital in this study, the mean found was $74 \%{ }^{(15)}$. Other studies that assess the workload of the nursing staff in non-COVID ICUs also found a lower NAS score, equivalent to $57.4 \%$ and $79.3 \%{ }^{(31-32)}$.

In a series of cases of patients affected by COVID-19 in Italy, an increase of $33 \%$ in the nursing workload was highlighted, compared to previous cases of the pandemic ${ }^{(6)}$. The increased workload is related to the severity of patients at admission and to procedures such as the prone maneuver, use of renal replacement therapy, IMV, and $\mathrm{ECMO}^{(6)}$.

In this research, 26 different NDs were listed, among which the most prevalent were Risk of infection (98.7\%), Self-care deficit syndrome (68.7\%), Impaired spontaneous ventilation (55.3\%), and Risk of pressure injury (50\%). These NDs portray the real needs of patients in the critical care environment, in which there is rapid instability and clinical severity, which requires the use of IMV in addition to other associated therapies. As a result, patients are confined to bed, with an impossibility for self-care and an increased risk of developing Pls. These findings are also demonstrated in other investigations whose objective was to assess the most prevalent NDs in the ICU (33-34).

Recently, members of the Rede de Pesquisa em Processo de Enfermagem (RePPE) [Nursing Process Research Network] published a study with strategies to favor the documentation of nurses' clinical practice in the COVID-19 pandemic. In it, they described NDs that could be used for critically ill patients with hypoxemic acute respiratory failure and those developing ARDS, such as "Impaired gas exchange" and "Impaired spontaneous ventilation"; they also pointed out other NDs that were found in our research ${ }^{(11)}$. In addition, there are review studies in the literature that also suggest NDs and nursing care that could be used at this time of pandemic, as they describe the needs of patients with COVID-19(10,35-37).

The NDs "Risk of shock" and "Risk for vascular dysfunction", although seldom used, reflect the pathophysiology of COVID-19 in critically ill patients. It is known that patients affected by COVID-19 are at risk of developing an intense inflammatory response, resulting in endothelial damage, with evidence of a pro-thrombotic state ${ }^{(38)}$. Therefore, care is needed regarding pulmonary and cardiac evaluation, as well as the observation of color, temperature and pulse of the extremities.

It is worth noting the low frequency of the "Impaired gas exchange" ND (8.7\%) in relation to the number of patients who were prone (20.6\%) and who were in IMV (66.7\%), considering that this is the most accurate ND for patients in need of prone maneuver. However based on the nurses' clinical judgment, the "Impaired spontaneous ventilation" ND was listed for the vast majority, considering the need for IMV upon admission and, subsequently, the need for prone maneuver. Furthermore, the NDs referring to the respiratory system are similar to each other and share similar defining characteristics; therefore, less accurate NDs end up being listed in certain situations ${ }^{(39)}$.

The frequency of the "Risk of pressure injury" ND was also lower than the number of patients who were on IMV, which is a condition associated with this type of injury. However, other NDs were also listed, which include nursing care to avoid PIs, such as: "Risk of impaired skin integrity" and "Impaired physical mobility".

In general, the nursing care prescribed by nurses is similar to that of another study carried out in the ICU and, for the most part, is related to the needs of patients in an intensive care environment, highlighting care for the prevention of infections and for body care ${ }^{(40)}$. Furthermore, the prevalence is linked to institutional protocols, such as care for preventing MV-associated pneumonia, prevention of catheter-related bloodstream infections, and preventive measures against falls.

Note that all NDs and prescribed care are focused on the physiological needs of patients. However, it is important to highlight that these patients have a great demand for psychosocial and psychospiritual needs, which were not evidenced in this research. In the case of a totally isolated patient, unable to receive visits from family members, afraid of the unknown disease and associated anxiety, these characteristics reflect on the response to the established treatment. In this sense, the role of the nursing team in providing support and attending to all these patients' needs along with the multidisciplinary team is highlighted.

It is worth mentioning that, despite not being documented, measures of relief and psychological comfort were instituted for both patients and family members. In the hospital in this study, the maxi badge was used to enable patients to identify professionals; and the use of cell phones was allowed for communication with the family, including video calls as a means of virtual visits.

\section{Study limitations}

As it is one of the first national surveys in the field of nursing to describe the characteristics of patients with COVID-19 in the ICU, a study limitation was that of being developed in a single center, with a sample referring to an initial period of the pandemic in Brazil. In addition, the study and sample design may have limited the analysis of some variables, such as obesity, IMV, and prone maneuver, which did not obtain a statistically significant value; for this reason, such results cannot be generalized, suggesting further studies. However, these findings are of great importance for reviewing the participating institution's internal processes.

\section{Contributions to the Nursing field}

The pandemic brought along several challenges and difficulties for nursing teams, but provided visibility to the profession, valuing the role of nurses as front-line combatants of the disease. Greater knowledge of the profile of critically ill patients with 
COVID-19 throughout 2020, through studies such as this one, has contributed to a more reliable assessment of health needs, with better organization of care and grounding in scientific evidence.

\section{CONCLUSION}

Patients with COVID-19 who required intensive care were mostly men with a mean age of 59 years and who had low education. The most frequently identified comorbidities were $\mathrm{SAH}$, obesity, and DM2, which were associated with an age over 60 years, except for obesity, which was prevalent in non-elderly patients.

Most patients required support therapies and different technologies such as IMV, prone maneuver, hemodialysis, and ECMO in the first 24 hours of hospitalization, demonstrating high clinical instability and increased complexity of care. As a result, the average NAS of patients was $86 \%$, showing a high workload of the nursing team, especially for patients who required the prone maneuver and dialysis therapy.

The identified NDs and nursing care highlighted the health needs of patients with COVID-19 admitted to the ICU, with ventilatory support, infection prevention, and skin care being of great importance for them. The most prevalent nursing care demonstrates the nursing team's adherence to institutional safety protocols, even during the critical period faced.

Nursing care was modified in the face of the pandemic, so that the operationalization of the NP becomes essential to guide the clinical practice of nurses. In addition, COVID-19 also changed the profile and complexity of patients admitted to the ICU, requiring unexpected organizational and care changes in order to provide an immediate response to the pandemic crisis.

Therefore, these results have great relevance for the nursing field, due to the understanding of changes in patients' profile. It is essential to reorganize management, human, and material resources and, above all, offer quality and safe nursing care to patients with COVID-19 in intensive care.

\section{FUNDING}

Postgraduate Program in Nursing at UFRGS - Budget PROAP.

\section{REFERENCES}

1. Ciotti M, Angeletti S, Minieri M, Giovannetti M, Benvenuto D, Pascarella S, et al. COVID-19 Outbreak: an overview. Chemother. 2020:1-9. https://doi.org/10.1159/000507423

2. World Health Organization (WHO). Report of the WHO-China joint mission on Coronavirus Disease 2019 (COVID-19) [Internet]. 2020 [cited 2020 Jun 12]. Available from: https://www.who.int/docs/default-source/coronaviruse/who-china-joint-mission-on-covid-19-final-report.pdf

3. Antunes C, Cunha AM, Hemkemaier ECR, Carmo KS, Moraes TVP, Santos TP, et al. Desafios e recomendações para o cuidado intensivo de adultos críticos com doença de coronavírus 2019 (COVID-19). Health Resid J[Internet]. 2020[cited 2020 Jun 12];1(1). Available from: https:// escsresidencias.emnuvens.com.br/hrj/article/view/20

4. Ruan Q, Yang K, Wang W, Jiang L, Song J. Clinical predictors of mortality due to COVID-19 based on an analysis of data of 150 patients from Wuhan, China. Intensive Care Med. 2020. https://doi.org/10.1007/s00134-020-05991-x

5. Grasselli G, Zangrillo A, Zanella A, Antonelli M, Cabrini L, Castelli A, et al. COVID-19 Lombardy ICU Network. Baseline Characteristics and Outcomes of 1591 Patients Infected With SARS-CoV-2 Admitted to ICUs of the Lombardy Region, Italy. JAMA. 2020;323(16):1574-81. https:// doi.org/10.1001/jama.2020.5394

6. Lucchini A, Giani M, Elli S, Villa S, Rona R, Foti G. Nursing Activities Score is increased in COVID-19 patients. Intensive Crit Care Nurs. 2020;59:e102876. https://doi.org/10.1016/j.iccn.2020.102876

7. Lucchini A, lozzo P, Bambi S. Nursing workload in the COVID-19 era. Intensive Crit Care Nurs. 2020;61:102929. https://doi.org/10.1016/j. iccn.2020.102929

8. Bruyneel A, Gallani MC, Tack J, d'Hondt A, Canipel S, Franck S, et al. Impact of COVID-19 on nursing time in intensive care units in Belgium. Intensive Crit Care Nurs. 2020;62:102967. https://doi.org/10.1016/j.iccn.2020.102967

9. Herdman TH, Kamitsuru S. NANDA international nursing diagnoses: definitions and classification 2018-2020. 11th ed. New York: Thieme; 2018.

10. Moorhead S, Macieira TGR, Lopez KD, Mantovani VM, Swanson E, Wagner C, et al. NANDA-I, NOC, and NIC Linkages to SARS-Cov-2 (Covid-19): Part 1, Community Response. Int J Nurs Knowl. 2020;32:59-67. https://doi.org/10.1111/2047-3095.12291

11. Barros ALBL, Silva VM, Santana RF, Cavalcante AMRZ, Vitor AF, Lucena AF, et al. Contribuições da rede de pesquisa em processo de enfermagem para assistência na pandemia de COVID-19. Rev Bras Enferm. 2020.73(2):e20200798. https://doi. org/10.1590/0034-7167-2020-0798

12. Horta WA. Processo de enfermagem. São Paulo (SP): EPU; 1979.

13. Bulechek GM, Butcher HK, Dochterman JM. NIC: Classificação das Intervenções de Enfermagem. Rio de Janeiro: Elsevier; 2016.

14. Queijo AF, Padilha KG. Nursing Activities Score (NAS): adaptação transcultural e validação para a língua portuguesa. Rev Esc Enferm USP. 2009;43(Esp):1018-25. https://doi.org/10.1590/S0080-62342009000500004

15. Batassini E, Silveira JT, Cardoso PC, Castro DE, Hochegger T, Vieira DFVB, et al. Nursing Activities Score: what is the ideal periodicity for assessing workload? Acta Paul Enferm. 2019;32(2):162-8. https://doi.org/10.1590/1982-0194201900023

16. CDC COVID-19 Response Team. Severe Outcomes Among Patients with Coronavirus Disease 2019 (COVID-19) - United States, February 12-March 16, 2020. MMWR Morb Mortal Wkly Rep. 2020;69(12):343-6. https://doi.org/10.15585/mmwr.mm6912e2 
17. Grasselli G, Zangrillo A, Zanella A, Antonelli M, Cabrini L, Castelli A, et al. Baseline Characteristics and Outcomes of 1591 Patients Infected With SARS-CoV-2 Admitted to ICUs of the Lombardy Region, Italy. JAMA. 2020;323(16):1574-81. https://doi.org/10.1001/jama.2020.5394

18. Pérez MF, Pino DL, García JJ, Ruiz MN, Méndez AE, Jiménez CG, et al. Comorbilidad y factores pronósticos al ingreso en una cohorte COVID-19 de un hospital general. Rev Clin Esp. 2020;221(9): 529-35. https://doi.org/10.1016/j.rce.2020.05.017

19. Cecília FLC, Ângela D, Cassiano T, Carolina HS, Anelise BT, Gilberto F. A adequação do suporte nutricional enteral na unidade de terapia intensiva não afeta o prognóstico em curto e longo prazos dos pacientes mecanicamente ventilados: um estudo piloto. Rev Bras Ter Intensiva. 2019;31(1):34-8. https://doi.org/10.5935/0103-507X.20190004

20. Lima DLF, Dias AA, Rabelo RS, Cruz ID, Costa SC, Nigri FMN, et al. COVID-19 no estado do Ceará, Brasil: comportamentos e crenças na chegada da pandemia. Ciên Saúde Coletiva. 25(5):1575-86. https://doi.org/10.1590/1413-81232020255.07192020

21. Hsu HE, Ashe EM, Silverstein M, Hofman M, Lange SJ, Razzaghi H, et al. Race/Ethnicity, underlying medical conditions, homelessness, and hospitalization status of adult patients with COVID-19 at an Urban Safety-Net Medical Center — Boston, Massachusetts, 2020. MMWR Morb Mortal Wkly Rep. 2020;69:864-9. https://doi.org/10.15585/mmwr.mm6927a3

22. Chow N, Dutra KF, Gierke R, Hall A, Hughes M, Pilishvili T, et al. Preliminary estimates of the prevalence of selected underlying health conditions among patients with Coronavirus Disease 2019 - United States, February 12-March 28, 2020. MMWR Morb Mortal Wkly Rep 2020;69:382-386. https://doi.org/10.15585/mmwr.mm6913e2

23. Teich VD, Klajner S, Almeida FA, Dantas AC, Laselva CR, Torritesi MG, et al. Características epidemiológicas e clínicas dos pacientes com COVID-19 no Brasil. Einstein (São Paulo). 2020;18:eAO6022. https://doi.org/10.31744/einstein_journal/2020AO6022

24. Barros GM, Filho JBRM, Mendes Jr AC. Considerações sobre a relação entre a hipertensão e o prognóstico da COVID-19. J Health Biol Sci. 2020;8(1):1-3. https://doi.org/10.12662/2317-3076jhbs.v8i1.3250.p1-3.2020

25. Roncon L, Zuin M, Rigatelli G, Zuliani G. Diabetic patients with COVID-19 infection are at higher risk of ICU admission and poor short-term outcome. J Clin Virol. 2020;127:104354. https://doi.org/10.1016/j.jcv.2020.104354

26. Targher G, Mantovani A, Wang XB, Yan HD, Sun QF, Pan KH, et al. Patients with diabetes are at higher risk for severe illness from COVID-19. Diabetes Metab. 2020;46(4):335-7. https://doi.org/10.1016/j.diabet.2020.05.001

27. Palaiodimos L, Kokkinidis DG, Li W, Karamanis D, Ognibene J, Arora S, et al. Severe obesity, increasing age and male sex are independently associated with worse in-hospital outcomes, and higher in-hospital mortality, in a cohort of patients with COVID-19 in the Bronx, New York. Metabolism. 2020;108:154262. https://doi.org/10.1016/j.metabol.2020.154262

28. Popkin BM, Du S, Green WD, Beck MA, Algaith T, Herbst CH, et al. Individuals with obesity and COVID-19: a global perspective on the epidemiology and biological relationships. Obes Rev. 2020;21(11):e13128. https://doi.org/10.1111/obr.13128

29. Matthay MA, Aldrich JM, Gotts JE. Treatment for severe acute respiratory distress syndrome from COVID-19. Lancet Respir Med. 2020;8(5):433-4. https://doi.org/10.1016/S2213-2600(20)30127-2

30. Perrillat A, Foletti JM, Lacagne AS, Guyot L, Graillon N. Facial pressure ulcers in COVID-19 patients undergoing prone positioning: how to prevent an underestimated epidemic? J Stomatol Oral Maxillofac Surg. 2020;121(4):442-4. https://doi.org/10.1016/j.jormas.2020.06.008

31. Salgado PO, Januário CF, Toledo LV, Brinati LM, Araújo TS, Boscarol GT. Carga de trabajo de enfermería requerida por los pacientes durante la hospitalización en una UCI: estudio de cohorte. Enferm Glob. 2020;19(59):450-78. https://doi.org/10.6018/eglobal.400781

32. Nassiff A, Araújo TR, Menegueti MG, Bellissimo FR, Basile AF, Laus AM. Carga de trabalho de enfermagem e a mortalidade dos pacientes em unidade de terapia intensiva. Texto Contexto Enferm. 2018;27(4):e0390017. https://doi.org/10.1590/0104-07072018000390017

33. Ferreira AM, Rocha EN, Lopes CT, Bachion MM, Lopes JL, Barros ALBL. Nursing diagnoses in intensive care: cross-mapping and NANDA-I taxonomy. Rev Bras Enferm. 2016;69(2):285-93. https://doi.org/10.1590/0034-7167.2016690214i

34. Martins CP, SMG, Brandão SMGA, Freire MTJ, Marques KMAP. Diagnósticos de enfermagem em uti: uma revisão integrativa. Rev Aten Saúde. 2018;16(57):74-86. https://doi.org/10.13037/ras.vol16n57.5124 ISSN 2359-4330

35. Bitencourt GR, Barbosa JES, Taets CMC, Ceccon DL, Coutinho RP, Taets GGCC. Padrões funcionais de saúde em adultos com covid-19 na terapia intensiva: fundamentando diagnósticos de enfermagem. Int J Develop Res. 2020;10(06):36540-4. https://doi.org/10.37118/ ijdr.19007.06.2020

36. Queiroz AGS, Souza RZ, Sottocornola SF, Barbosa SJ, Pinheiro FA, Souza LP. Diagnósticos de enfermagem segundo a taxonomia da NANDA internacional para sistematização da assistência de enfermagem a COVID-19. J Health Biol Sci. 2020;8(1):1-6. https://doi.org/10.12662/23173206jhbs.v8i1.3352.p1-6.2020

37. Dantas TP, Aguiar, CAS, Rodrigues VRT, Silva RRG, Silva MIC, Sampaio LRL, Pinheiro WR. Diagnósticos de enfermagem para pacientes com COVID-19. J. Health NPEPS. 2020;5(1):396-416. https://doi.org/10.30681/252610104575

38. Nascimento JHP, Gomes BFO, Carmo JPR, Petriz JLF, Rizk SI, Costa IBSS, et al. COVID-19 e Estado de Hipercoagulabilidade: uma nova perspectiva terapêutica. Arq Bras Cardiol. 2020;114(5):829-33. https://doi.org/10.36660/abc.20200308

39. Vieira LF, Fernandes VR, Papathanassoglou E, Azzolin KO. Accuracy of defining characteristics for nursing diagnoses related to patients with respiratory deterioration. Int J Nurs Knowl. 2020;31(4):262-7. https://doi.org/10.1111/2047-3095.12272

40. Camargo MM, Furieri LB, Lima EFA, Lucena AF, Fioresi M, Romero WG. Cross mapping between clinical indicators for assistance in intensive care and nursing interventions. Rev Bras Enferm. 2020;73(6):e20190728. https://doi.org/10.1590/0034-7167-2019-0728 